Saudi Journal of Medical and Pharmaceutical Sciences

Abbreviated Key Title: Saudi J Med Pharm Sci ISSN 2413-4929 (Print) |ISSN 2413-4910 (Online) Scholars Middle East Publishers, Dubai, United Arab Emirates Journal homepage: https://saudijournals.com/sjmps

Original Research Article

\title{
Preliminary Phytochemical Evaluation and HPTLC Profile of Celastrus paniculatus Seed
}

Shashank Dhar Tiwari", Tyagi CK, Prabhakar Budholiya

College of Pharmacy, SSSUTMS, Sehore (M.P) India

DOI: $10.36348 /$ sjmps.2020.v06i11.004 $\quad$ | Received: 21.10.2020 | Accepted: 05.11.2020 | Published: 11.11 .2020

*Corresponding author: Shashank Dhar Tiwari

\section{Abstract}

Standardization plays a significant part in the production of phytopharmaceutical of standard quality as the quality standards are based on proper selection of raw materials. Celastrus paniculatus Willd (Celastraceae) is the conventional Ayurvedic medicinal plant used for centuries as a memory enhancing, anti-inflammatory, analgesic, sedative and antiepileptic agent. The decoction of seeds is given in rheumatism, gout, paralysis and leprosy. High Performance Thin Layer Chromatography (HPTLC) technique is a sophisticated and automated form of the thin-layer chromatography (TLC) with enhanced and advanced separation efficiency and detection limits and is often an outstanding alternative to GC and HPLC. Applications of HPTLC include phytochemical and biomedical analysis, herbal drug quantification, active ingredient quantification, fingerprinting of formulations, and check for adulterants in the formulations. Present investigation includes examination of morphological and microscopic characters, ash value, extractive values and phytochemical evaluations including qualitative chemical examination of active constituents. The Pet. Ether extract (i.e. oil) contains different fatty acids and they were converted into their methyl esters for their assessment by HPTLC.

Keywords: Celastrus paniculatus seed, phytochemical, phytoconstituent, pharmacognostic \& HPTLC analysis.

Copyright (C) 2020 The Author(s): This is an open-access article distributed under the terms of the Creative Commons Attribution 4.0 International License (CC BY-NC 4.0) which permits unrestricted use, distribution, and reproduction in any medium for non-commercial use provided the original author and source are credited.

\section{INTRODUCTION}

Standardization plays a significant role in the production of phytopharmaceutical of standard quality as the quality standards are based on proper selection of raw materials. As very little specific standards are mentioned in the official monographs evaluation of the crude drugs is of great consequence for the pharmaceutical industry. This involves the determination of identity and purity of quality. Many organic \& inorganic contaminants which are virtually impossible to avoid while collecting crude drugs affect the purity of any crude drug which needs proper assessment \& detection based on different pharmacognostic \& phytochemical parameters [1]. An herbal drug constitutes a major part in all traditional systems of medicine. There are approximately 1250 Indian medicinal plants which are used in formulating therapeutic preparations according to Ayurvedic and other traditional systems of medicine [2]. Celastrus paniculatus Wild. Mentioned in Ayurveda as 'Tree of life', (Celastraceae) was in use from time immemorial to treat brain related disorders and to enhance learning and memory. C. paniculatus exhibited many activities along with main activity i.e memory enhancing effect.

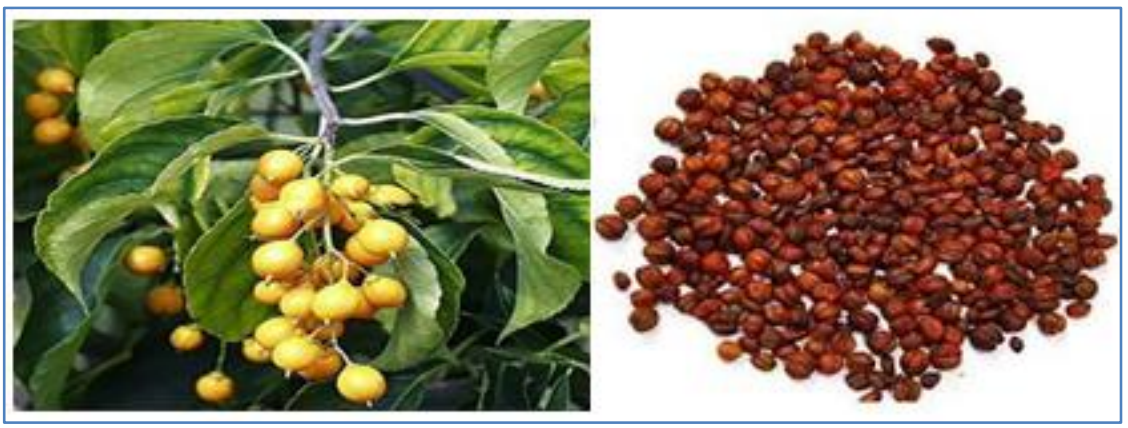


Various reported activities are antiviral, antibacterial, insecticidal, anti-inflammatory, antispermatogenic, sedative, anti-fatigue and analgesic, hipolipidemic. It is arthralagenic, antirhumatic, aphrodisiac, emetic, laxative, nervine tonic [3, 4].

\section{Materials AND MethodS}

\section{Collection and authentication}

Seed of Celastrus paniculatus seed were collected from local market of Bhopal (M.P.) and authenticated.

\section{Preparation of Plant Extracts}

About $200 \mathrm{~g}$ dried powder of Celastrus paniculatus seeds was extracted with $800 \mathrm{ml}$ of petroleum ether (40-600C) at temperature of 40-500C. The extraction was continued until the solvent in the thimble became clear. Then extract was filtered, the solvent was distilled off and the extract was concentrated on water bath till an oily extract was obtained.

\section{Preliminary phytochemical screening of plant extracts [5-8] \\ Characterization of Seed oil of Celastrus paniculatus Acid Value}

$2 \mathrm{~g}$ oil was weighed accurately by transfer method into a $250 \mathrm{ml}$ conical flask. Neutral ethanol (20 $\mathrm{ml}$ ) was added by means of a pipette and the flask heated on a steam bath for $3 \mathrm{~min}$. Then the flask was cooled and the contents were titrated with $0.1 \mathrm{M}$ alcoholic $\mathrm{KOH}$ solution using phenolphthalein as an indicator. A blank titration was also conducted side by side.

Acid value $=5.61 * n$

\section{Iodine Value}

$2 \mathrm{~g}$ oil was weighed accurately by transfer method into a $250 \mathrm{ml}$ iodine flask and dissolved in chloroform $(20 \mathrm{ml})$. Wij's reagent [Iodine monochloride] $(20 \mathrm{ml})$ was added by means of a pipette. The flask was stopper and kept in darkness for one hour with intermittent shaking. Then $15 \%$ of potassium iodide solution $(10 \mathrm{ml})$ and $50 \mathrm{ml}$ of distilled water were added to the flask and mixture was shaken well. The liberated iodine was titrated with $0.1 \mathrm{M}$ sodium thiosulphate solution using fresh starch solution as indicator. A blank titration was also conducted side by side.

\section{Saponification value}

$2 \mathrm{~g}$ oil was weighed accurately by transfer method into a $250 \mathrm{ml}$ round bottom flask. Freshly prepared $0.5 \mathrm{M}$ alcoholic potassium hydroxide solution $(25 \mathrm{ml})$ was added to the sample by means of pipette and the mixture gently refluxed on a steam bath using an air-condenser for one hour. Then the flask was cooled to about $60-700 \mathrm{C}$, the condenser tip washed with little distilled water and the contents were titrated with $0.5 \mathrm{M} \mathrm{HCl}$ solution using phenolphthalein as indicator. A blank titration was carried out simultaneously.

\section{Preliminary qualitative test}

The various extract of Celastrus paniculatus seed was subjected to preliminary qualitative phytochemical investigation. The various tests and reagent used are given below.

\section{Alkaloids}

Preparation of test solution: The test solution was prepared by dissolving extracts in the dilute hydrochloric acid.

Mayer' test: The acidic test solution with Mayer's reagent (Potassium Mercuric iodide) gave cream colored precipitate.

Hager's test: The acidic test solution with Hager's reagent (Saturated picric acid solution) gave yellow precipitate.

Dragendorff's test: The acidic solution with Dragendorff's reagent (Potassium bismuth iodide) showed reddish brown precipitate.

Wagner's test: The acidic test solution treated with Wagner's reagent (Iodine in potassium iodide) gave brown precipitate.

Tannic acid test: The acidic test solution treated with Tannic acid gave buff colour precipitate.

Picrolonic acid test: Alkaloids gave yellow colour precipitate with picrolonic acid.

\section{Amino acid}

Millon'test: To the test solution add about $2 \mathrm{ml}$ of millon's reagent white precipitate indicates presence of amino acid.

Ninhydrine test: To the test solution add Ninhydrine solution, boil, violet colour indicates presence of amino acid.

\section{Carbohydrates}

Preparation of test solution: The test solution was prepared by dissolving the test extracts with water. Then it was hydrolyzed with 1 volume of $1 \mathrm{~N}-\mathrm{HCL}$ and subjected to following chemical test.

Molisch's test: Test solution with few drops of Molisch's reagent and $2 \mathrm{ml}$ of conc. $\mathrm{H}_{2} \mathrm{So}_{4}$ added slowly from the sides of the test tubes. It showed a purple ring at the junction of two liquids. 
Barfoed's test: $1 \mathrm{ml}$ of test solution is heated with $1 \mathrm{ml}$ of Barfoed, s reagent on water bath, if red cupric oxide is formed, monosaccharide is present. Disaccharides on prolong heating (about $10 \mathrm{~min}$.) may also cause reduction, owing to partial hydrolysis to monosaccharide.

Benedict's test: Test solution treated with Benedict' reagent and after boiling on water bath, it showed reddish brown precipitate.

Fehling's test: The test solution when heated with equal volume of Fehling's A and B solution, gave orange red precipitate, indicating the presence of reducing sugars

\section{Flavonoids}

The flavonoids are all structurally derived from the parent substance called flavones. The flavonoids occur in the free from as well as bound to sugars as glycosides. For this reason, when analyzing flavonoids it is usually better to examine the flavonoids in hydrolyzed plant extracts.

Preparation of test solution: To a small amount of extract added equal volume of $2 \mathrm{M} \mathrm{HCL}$ and heated in a test tube for 30 to $40 \mathrm{~min}$ at $100^{\circ} \mathrm{C}$. The cooled extract was filtered, and extracted with ethyl acetate The ethyl acetate was concentrated to dryness, and used to test for flavonoids.

Shinoda test: Test solution with few fragments of magnesium ribbon and conc. HCL showed pink to magenta red colour.To a small quantity of test solution when lead acetate solution was added, it formed yellow colored precipitate.

Alkaline reagent test: Test solution when treated with sodium hydroxide solution showed increase in the intensity of yellow colour, which becomes colorless on addition of few drops of dilute acid.

\section{Glycosides}

Preparation of test solution: The test solution was prepared by dissolving extract in the alcohol or hydroalcoholic solution.

\section{Test for Cardiac glycosides}

Kedde' test: Add one drop of $90 \%$ alcohol and 2 drops of $2 \%$ 3, 5- dinitro benzoic acid in 90\% alcohol. Make alkaline with $20 \%$ sodium hydroxide solution, purple colour is produced. The colour reaction with 3,5-dinitro benzoic acid depends on the presence of $\alpha, \beta$-unsaturated lactones in the aglycone.

Baljet's test: The test solution treated with sodium picrate gave yellow to orange colour.
Raymond's test: Test solution treated with hot methanolic alkali, violet colour is produced.

Bromine water test: Test solution dissolve in bromine water give yellow precipitate.

Keller-killani test for digitoxose: The test solution treated with few drops of Fecl3 solution and mixed, then $\mathrm{H}_{2} \mathrm{So}_{4}$ containing Fecl3 solution was added, it formed two layers. Lower layer reddish brown, upper layer turns bluish green.

Legal's test: Test solution when treated with pyridine (made alkaline by adding sodium nitroprusside solution) gave pink to red colour.

\section{Test for anthraquinone glycosides}

Borntrager's test: Boiled powdered drug with $5 \mathrm{ml}$ of $10 \%$ sulphuric acid for five minutes. Filtered while hot, cooled the filtrate shaken gently with equal volume of benzene. Benzene layer was separated and then treated with half of its volume solution ammonia (10\%). Allowed to separate it. The ammonical layer acquired rose pink colour due to presence of anthraquinones.

\section{Proteins}

Preparation of test solution: The test solution was prepared by dissolving the extract in water.

Millon's test: Test solution was treated with millon's reagent and heated on a water bath. The proteins were stained red

Biuret test: Test solution was treated with $40 \%$ sodium hydroxide and dilute copper sulphate solution gave blue colour.

Xanthoproteic test: Test solution was treated with conc. $\mathrm{HNO}_{3}$ and boiled which gave yellow precipitate.

Modified Borntrager's test: C-glycosides of anthraquinones require more drastic conditions for hydrolysis. Hydrolysis of the drug was carried out with $5 \mathrm{ml}$ of dilute of HCL and $5 \mathrm{ml}$ of $5 \%$ solution of $\mathrm{Fecl}_{3}$. For hydrolyzed extract procedure was carried out as described under Borntrager's test.

\section{Test for steroids}

Preparation of test extract solution: The extract was refluxed separately with alcoholic solution of potassium hydroxide till complete saponification. The saponified extract was diluted with water and unsaponificable matter was extracted with diethyl ether. The ethereal extract was evaporated and the residue (saponificable matter) was subjected to the following test by dissolving the residue in the chloroform. 
Salkowski test: To the test extract solution add few drops of conc. $\mathrm{H}_{2} \mathrm{SO}_{4}$ shaken and allowed to stand, lower layer turned red indicating the presence of steroids.

Libermann - Burchard test: The test solution treated with few drops of acetic anhydride and mixed, when conc. $\mathrm{H}_{2} \mathrm{SO}_{4}$ was added from the sides of the test tubes, it showed a brown ring at the junction of the two layers and the upper layers turned green. Added few drops of concentrated $\mathrm{H}_{2} \mathrm{SO}_{4}$. Blue colour appeared.

Sulphur test: Sulphur test when added in to the test solution, it sank it.

\section{Tannins and phenol compound}

To 2-3 $\mathrm{ml}$ of alcoholic or aqueous extract, added few drops of following reagents.

$5 \%$ Fecl $_{3}$ solution: Deep blue- black colour

Lead acetate solution: White precipitate.

Bromine water: Discoloration of bromine water

Acetic acid solution: Red colour solution.

Dilute iodine solution: Transient red colour.

One drop of $\mathrm{NH}_{4} \mathrm{OH}$, excess $10 \% \mathrm{AGNO}_{3}$ solution. Heated for $20 \mathrm{~min}$ in boiling water bath. White precipitate was observed, then dark silver mirror deposited on wall of test tube.

\section{Triterpenoids}

Preparation of test extract solution: The test extract solution was prepared by dissolving extract in the chloroform.

Salkowski test: Few drops of concentrated sulphuric acid were added to the test solution, shaken and on standing lower layer turned golden yellow [8$10]$.

\section{HPTLC of methyl esters and seed oil}

Petroleum ether $\left(40-60^{\circ} \mathrm{C}\right)$ extract and methyl esters of fatty acids were subjected to HPTLC. The details of

HPTLC were as follows.

Plate

Thickness

: SilicagelGF 254 plate

PlateSize

$: 0.2 \mathrm{~mm}$

: 10x $10 \mathrm{cms}$

Sample application $\quad: 10 \square 1$

Solventsystem

: Hexane: Acetone (9.5:0.5)

Detecting reagent: $1 \% \mathrm{w} / \mathrm{v}$ solution of 2,7 dichlorofluorescein in alcohol Sample application was carried out using LINOMAT-V and CAMAGTLC .Scanner 3 densitometric evaluation system with WINCAT software was used for scanning of thin layer chromatogram objects in reflectance or transmission mode by absorbance or by fluorescence at 254 or 366 $\mathrm{nm}$ respectively.

Table-1: Percent yield and physical evaluation of extracts

\begin{tabular}{|c|c|c|c|c|c|}
\hline Sr. No. & Extract & $\begin{array}{c}\text { Nature of } \\
\text { Extract }\end{array}$ & Colour & Weight & \% Yield \\
\hline 1. & Pet. Ether $\left(40-60^{0}\right)$ & Liquid (Oil) & Reddish brown & $168 \mathrm{~g}$ & $33.33 \% \mathrm{w} / \mathrm{w}$ \\
\hline 2. & Alcohol & \multirow{2}{*}{ Semi solid } & Brownish black & $47 \mathrm{~g}$ & $26.85 \% \mathrm{w} / \mathrm{w}$ \\
\cline { 4 - 5 } & Ethyl acetate & Dark brown & $6.5 \mathrm{~g}$ & $21.66 \% \mathrm{w} / \mathrm{w}$ \\
\hline
\end{tabular}

Table-2: Physiochemical parameter Celastrus paniculatus seeds

\begin{tabular}{|l|c|}
\hline Oil Characteristic & Result \\
\hline Acid value & 3.58 \\
\hline Saponification value & 219.51 \\
\hline Ester value & 215.93 \\
\hline Iodine value & 104.46 \\
\hline Unsaponifiable matter & 0.1960 \\
\hline
\end{tabular}


Table-3: Phytochemical analysis of different extract of Celastrus paniculatus seeds $D C$

\begin{tabular}{|c|c|c|c|c|}
\hline $\begin{array}{l}\text { Sl. } \\
\text { No. }\end{array}$ & Phytoconstituent & $\begin{array}{c}\text { Pet. Ether }\left(40-60^{0} \mathrm{C}\right) \\
\text { extract }\end{array}$ & Alcoholic extract & $\begin{array}{c}\text { Ethyl acetate fraction of } \\
\text { Alcoholic extract }\end{array}$ \\
\hline 1. & Carbohydrates & - & - & - \\
\hline 2. & Proteins & - & - & - \\
\hline 3. & Amino acids & - & - & - \\
\hline 4. & Fats and oils & + & + & + \\
\hline 5. & Steroids & + & + & - \\
\hline 6. & Glycosides & - & - & - \\
\hline 7. & Alkaloids & + & + & - \\
\hline 8. & Tannins & - & + & - \\
\hline 9. & Vitamins & - & - & - \\
\hline 10. & Flavonoids & - & + & + \\
\hline 11. & Triterpenoids & + & + & + \\
\hline
\end{tabular}

Table-4: Peak table showing HPTLC profile (at $366 \mathrm{~nm}$ after derivatization) of methyl ester and seed oil of Celastruspaniculatus Willd

\begin{tabular}{|c|c|c|c|c|c|c|c|c|c|}
\hline Peak & $\begin{array}{c}\text { Start } \\
\text { Rf }\end{array}$ & $\begin{array}{c}\text { Start } \\
\text { Height }\end{array}$ & $\begin{array}{c}\text { Max } \\
\text { Rf }\end{array}$ & $\begin{array}{c}\text { Max } \\
\text { Height }\end{array}$ & $\begin{array}{c}\text { Max } \\
\%\end{array}$ & $\begin{array}{c}\text { End } \\
\text { Rf }\end{array}$ & $\begin{array}{c}\text { End } \\
\text { Height }\end{array}$ & Area & $\begin{array}{c}\text { Area } \\
\%\end{array}$ \\
\hline \multicolumn{1}{|c|}{ Track 1, ID: Methyl esters of Celastruspaniculatusseed oil } \\
\hline 1 & 0.03 & 1 & 0.08 & 148.2 & 25.48 & 0.16 & 1.6 & 4243.8 & 19.36 \\
\hline 2 & 0.31 & 19.7 & 0.38 & 39.7 & 6.82 & 0.4 & 35 & 1621.4 & 7.4 \\
\hline 3 & 0.41 & 33.6 & 0.5 & 214.4 & 36.87 & 0.56 & 28.1 & 10379.8 & 47.35 \\
\hline 4 & 0.66 & 15.5 & 0.72 & 24 & 4.13 & 0.79 & 0.2 & 1318.3 & 6.01 \\
\hline 5 & 0.79 & 0.1 & 0.83 & 29.6 & 5.09 & 0.86 & 20.6 & 837.5 & 3.82 \\
\hline 6 & 0.87 & 18.9 & 0.92 & 29.5 & 5.08 & 0.96 & 8.2 & 1237.6 & 5.65 \\
\hline
\end{tabular}

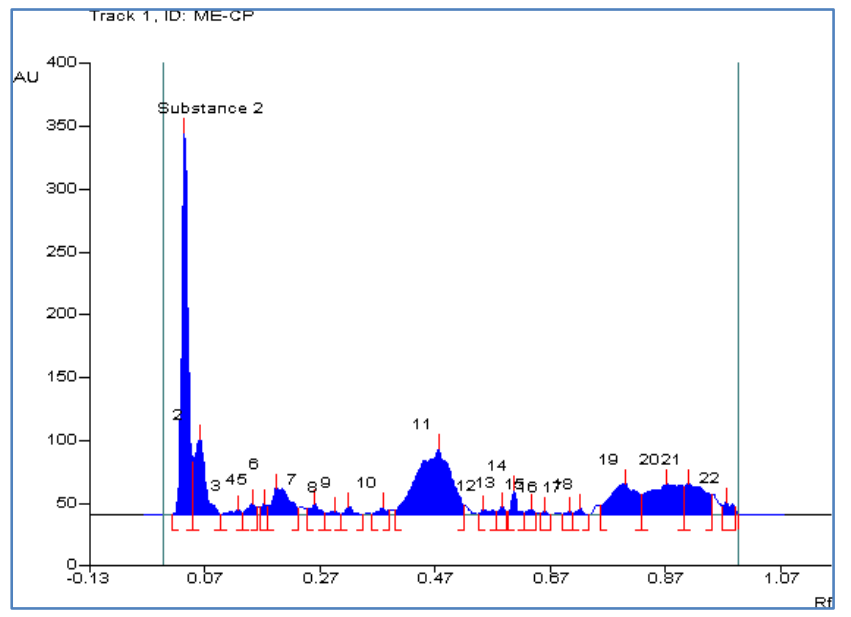

Fig-1: HPTLC profile of methyl esters of $C$. paniculatusat $366 \mathrm{~nm}$ before derivatization

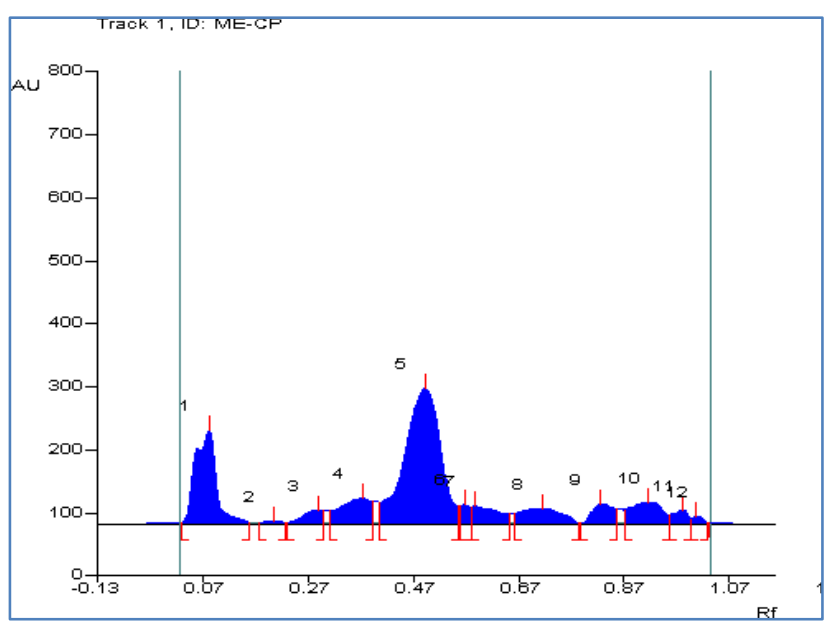

Fig-2: HPTLC profile of methyl esters of C. paniculatusat $366 \mathrm{~nm}$ after derivatization 


\section{RESUlT AND DisCUSSION}

It is seen from the literature that Celastrus paniculatus seeds is a very important plant for its large number of medicinal properties. The plant shows many pharmacological activities likes anti-inflammatory, antispermatogenic, sedative, anti-fatigue and analgesic, hipolipidemic. The seed oil was characterized by different physical constants such as acid value (3.58), iodine value (104.46), saponification value (219.51), ester value (215.93) and unsaponifiable matter $(0.1964$ g) (Table No.1). Dried powder of seeds of C. paniculatus was subjected to extraction with Pet. Ether (40-600C) and alcohol. The \% yield of extracts was obtained to be $33.33 \% \mathrm{w} / \mathrm{w}$ and $26.85 \% \mathrm{w} / \mathrm{w}$, respectively. The alcoholic extract $(30$ g) was fractionated with Ethyl acetate. The \% yield of ethyl acetate fraction was obtained $21.66 \% \mathrm{w} / \mathrm{w}$ (Table No.2). The preliminary phytochemical investigation revealed the presence of various phytoconstituents in each extract and fraction (Table No. 3). The result revealed that Pet. ether extract showed presence of Sterols, Fats and oil, Triterpenoids, Alkaloids whereas alcoholic extract showed presence Alkaloids, Flavonoids, Fats and oil, Sterols and Tannins. The fraction of ethyl acetate fraction revealed presence of the Fats, Sterols and Flavonoids. The Pet. Ether extract (i.e. oil) contains different fatty acids and they were converted into their methyl esters for their assessment by HPTLC. The HPTLC profile of methyl esters was carried out showing different bright fluorescent spots of yellow color for mixed methyl esters at $\mathrm{R}_{\mathrm{f}}$ value of $0.08,0.38$, $0.50,0.72,0.83$ and 0.92 after derivatization with $1 \%$ alcoholic solution of 2, 7- dichlorofluorescein dye at $366 \mathrm{~nm}$ (Table No. 4). The conversion of fatty acids into methyl esters was confirmed and the methyl esters.

\section{CONCLUSION}

The present study may be useful to supplement information in regard to its characterization and identification of plant.

\section{REFERENCE}

1. Soni, H., Nayak, G., Mishra, K., Singhai, A. K., \& Pathak, A. K. (2010). Pharmacognostic and Phytochemical Evaluation of peel of Punica Granatum

2. Jitender, K. M, \& Saurabh, S. (2019). Botanicals Used for Anti-Hyperlipidemic Activity: A Review. Ijppr.Human, 15(3): 25.

3. Ketakee, D.K., Deodhar, N., Shinde, W. (2015). Celastrus paniculatus; medicinal and pharmacological properties: a review. 2015. International Journal of Development Research 5(09):5526-5531

4. Soni, H., Nayak, G., Mishra, K., Singhai, A. K., \& Pathak, A. K. (2010). Pharmacognostic and Phytochemical Evaluation of peel of Punica Granatum.

5. Soni, H., Nayak, G., Mishra, K., Singhai, A. K., \& Pathak, A. K. (2010). Evaluation of Phyto Pharmaceutical and Antioxidant Potential of Methanolic Extract of Peel of Punica granatum. Research Journal of Pharmacy and Technology, 3(4), 1170-1174.

6. Khandelwal, K.R. (1996). Practical Pharmacognosy. $\quad 3^{\text {rd }}$ edition. Pune: Nirali Prakashan, 165.

7. Soni, H., Nayak, G., Mishra, K., Singahi, A. K., \& Pathak, A. K. (2010). Pharmacognostic and Phytochemical Evalution of Leaves of Coleus aromaticus. International Journal of Pharmacology and Biological Sciences, 4(4), 71.

8. Soni, H., Nayak, G., Mishra, K., Singhai, A. K., \& Pathak, A. K. (2010). Evaluation of Phyto Pharmaceutical and Antioxidant Potential of Methanolic Extract of Peel of Punica granatum. Research Journal of Pharmacy and Technology, 3(4), 1170-1174.

9. Bhavesh, V., Sandip, B., Leena, S. (2013). Pharmacological activities of Celastrus paniculatus seeds: An overview. IJPS, 4(4); 264. 